\title{
Metarithmisis in Greece: The Emergence of Mediterranean Regimes
}

\author{
Dr. Nancy A. Vamvakas, University of Western Ontario \\ Department of Political Science, Adjunct Professor
}

A top-down analysis reveals that there is a change in the relationship between national and subnational authorities which can be attributed to the challenges facing industrialized countries in general, and European Union $(E U)$ member states in particular. Indeed, in the 1980 s, the region has been rediscovered by political economists, political scientists, and sociologists. On the one hand, people are turning to their territory as a way of reclaiming what is threatened. On the other, the region can portray itself as an asset on the global market because it is often better able to interact with the growing number of small and medium- sized firms. Decentralization has taken place across much of Europe; reforming the structures of subnational government can be seen as another attempt to modernize political systems. There is also a connection between $E U$ structural policy and decentralization. In the post-1988 period, structural funds provided an opportunity for subnational authorities to influence $E U$ decision-making, and have provoked a decentralist response from central and subnational authorities (Marks, 1992; Bullmann, 1997; Jeffery, 1997). Structural programmes attempt to alleviate economic disparities through transfers and to enhance the competitive capacity of regions. They also seek to arm regions with the necessary infrastructure and skills needed to compete in the internal market. Politically, one aim is to gain the support of peripheral actors by showing them Vamvakas, Nancy A. "Metarithmisis in Greece: The Emergence of Mediterranean Regimes." Federal Governance: A Graduate Journal of Theory and Politics. 4.1 (2004) $<$ http://www.cnfs-rcef.net/federalgovernance/content/volume4/articles/Nancy_Vamvakas.pdf $>$ 
the benefits of $E U$ membership. More importantly, there are prerequisites as to process which respect the principles of subsidiarity and partnership with the regions which can empower regional actors. ${ }^{1}$ So, this is a co-operative approach to structural programming. The European Commission in particular is a strong advocate and supporter of regional participation, and at times, 'selectively mobilizes actors, including particularly subnational governments to help formulate and support initiatives' (Marks, 1996). This is not surprising because the regions bring a practical experience to the policy process which is much needed for the type of development that the policy seeks to achieve (Keating and Hooghe, 1996). Further, information for evaluation and monitoring encourages, and in some respects necessitates, a bottom-up approach to policy-making. The Commission encourages subnational actors in cases where such involvement results in a more effective policy or where there is weak national resistance (Hooghe, 1996). Where a regional tier of government exists, the Commission often stimulates and coordinates local actors (Bullman, 1997).

It can be argued that the 1988 reforms of $E U$ structural programmes marked a shift towards a new type of politics which involved new ways of thinking found in the new development model and new regionalism. The old development approach of the Keynesian school redistributed income to stimulate less favoured regions. The aim was to shield the region from the negative effects of the market, and the region's role was to

\footnotetext{
1 "Subsidiarity" comes from the Latin 'subsidium' which is a military term for auxiliary forces later generalized to mean help or support. As a principle it assumes a co-operative style of policy-making which favours the lowest level. The principle has its roots in the 17thC writings of Johannes Althusius whose work Politica methodice digesta focuses on multiple consociations where power is allocated to the lowest possible level or consociation. It is not, however, a means to delineate competencies indefinitely; rather
} 
shield local producers from the effects of market competition (Nanetti, 1996; Amin, 1999). This was a top-down approach which was applied universally to all types of regions. New developments, however, emphasizes competitive growth. This politics is complex, diverse, and beyond the boundaries of the nation state; authority is dispersed and sovereignty is shared. In addition, the new paradigm seeks to unlock the wealth of regions (Amin, 1999). It stresses endogenous capacity, human capital training, research and innovation, and the stimulation of networks. Emphasis is placed on institutional cooperation between levels of government, and on networking between public and private entities.

Although there is no direct connection, this new development theory uses similar language found in regime theory. Clarence Stone introduced the notion of a regime in the American context. It can be defined as a constellation of public and private actors who make policy. It is an informal, relatively stable coalition which has access to institutional resources that enable it to have a sustained role in making governing decisions (Stone, $1989,1989 b)$. There is a connection here to early policy analysis which looks at communities and networks. Regime theory also has antecedents in machine politics and neo-elitist notions of 'mobilization of bias.' The regime school however, goes further. It is not a hierarchical unit, but a network of elected officials, business elites, and other groups who realize their mutual dependency and seek to co-operate and reach consensus. Although, it borrows from the economic paradigm by stressing the importance of business to the community, local politicians are not at the mercy of capital. Rather, they 
assume a brokerage role in forming a governing coalition. So, politics are important here. To be effective, governments realize that they must blend their capacities with those of non-governmental actors. Players hold strategically important positions and collectively are able to provide what individually they cannot. This is an intricate exchange, a partnership where each player exacts linkages from the other. Consequently, the role of government becomes that of mobilizer and co-ordinator of resources.

The literature on EU member states (Keating and Jones, 1995; Keating, 1998;

Hooghe, 1996; De Rynck, 1996; Balme and Jouve, 1996; Jouve, 1997; Loughlin, 1997) points to a connection between structural programmes and decentralization. EU structural policy penetrates member states by engaging national, subnational, and Commission officials. The end result is that this affects the centre-periphery nexus in member states (Marks, 1996). Central elites of $E U$ member states are realizing the need to gain legitimacy and information from actors on the ground, and this makes partnership more appealing to them (Marks, 1996; Hooghe, 1996). So, central actors co-operate because it is beneficial, not because of rules and regulations outlining procedures forcing them to co-opt regions as partners when framing and implementing regional programmes. In this policy-community "each player needs to exchange resources with other actors so that they can exert powers and this compels all players to consolidate their relationship in more or less durable arrangements." 2 There is an incentive to co-operate because constitutional authority is not enough, there is a need for information, funds, expertise, legitimacy and a capacity to organize (Hooghe, 1996a). So, again there are parallels to

\footnotetext{
${ }^{2}$ Liesbet Hooghe (1996a), “Introduction.” In L. Hooghe ed. Cohesion Policy and European Integration.
} 
regime theory.

Approaching the problem from the bottom-up, it can be argued that $E U$

membership in general, and structural funding in particular, mobilize subnational actors. The added financing which structural funds provide have offered regional actors a 'potof-gold.' Further, the ally they have found in the Commission and the new roles offered regions have combined to give regional actors a voice in regional policy. Indeed, regional actors use whatever relay they can to influence $E U$ policies. Although we have not witnessed a 'Europe of the Regions,' there has been a regionalization of Europe (Keating and Jones, 1985 and 1995; Keating and Hooghe, 1996; Hooghe, 1996; Marks, 1992, 1996; Bullmann, 1997; Jeffery, 1997; Loughlin, 1997; Sharpe, 1980, 1993). That is, the nation state remains the primary actor in EU politics (Keating and Hooghe, 1996), but there is also an increased role for regional actors in the area of $E U$ politics. This is particularly so in the implementation stage of structural policy because it establishes a direct nexus between subnational and supranational actors thereby eroding the traditional gate-keeping role of national governments (Hooghe, 1996). European, subnational and national actors become intermeshed in multiple policy networks, often blurring the distinction between the three levels (Hooghe, 1996).

This co-operative approach of structural policy alters centre-periphery relations. Indeed, if we examine the situations of member states, before and after cohesion policy, we can determine the impact of cohesion policy on the territorial restructuring of member states (Hooghe, 1996a). Even if it does not affect institutions, it does affect politics (Hooghe, 1996a). This article focuses on the decentralist changes that $E U$ structural 
policy has effected on Greek politics. Although much has been written on member states of the $E U$ and their regions, Greece has not received comparable attention from the academic community. Most noteworthy are the contributions made by such Greek scholars as Ioakimidis $(1994,1996,1996 a, 1998)$, Kazakos $(1991,1994)$, Plaskovitis (1994, 2000), and Papageorgiou and Verney (1992). Here, I make a modest attempt to fill some of this void.

Formally, the Greek state is structured along Napoleonic lines with a centralized administration, a legalistic constitution, and an ordered bureaucracy. The French model, characteristic of southern European states, combines strong state centralism with Jacobinism both in the central political and administrative structure, and in the bureaucracy. There is a Prefectoral administrative structure which divides the country into administrative districts each headed by a centrally appointed Prefect who supervises public services in the region. In practice however, clientelism penetrates the system so that the formal and informal political system are not aligned. Clientelism has a long tradition in Greece and can be traced to the pre-modern Greek state. Over the years, clientelism has assumed new guises, but it is very much a part of Greek politics. Indeed, modern Greek politics cannot be understood without a proper understanding of the practice of clientelism (Legg, 1969; Tsoukalas, 1993; Mouzelis, 1990). Clientelism has both a cultural and structural explanation in Greece. On the one hand, the practice of clientelism has become entrenched in the culture and it is passed from generation to generation. Hence, from a cultural perspective it can be argued that clientelism is a 'social condition' (Tsoukalas, 1993). On the other hand, from a structural perspective, it can be argued that clientelism is a channel of influence; it is a response to the 
institutional dependence of subnational levels of government on the politicoadministrative system (Médard, 1981). Given that clientelism can be a nebulous concept, given that it is generally accepted by the academic community as being part of the Greek political culture (Legg, 1969; Tsoukalas, 1993; Mouzelis, 1990), and given the space constraint, I will not be delving into this area in this article. ${ }^{3}$ I will, however, assume its presence in the Greek system and proceed from there to consider the centreperiphery nexus.

The structural programmes of the European Union $(E U)$ represent an economic opportunity for Greece, but the Greek political system has had trouble implementing them effectively and hence, it has not been able to take full advantage of the Funds. Centralization and the exclusion of subnational actors are not conducive to comprehensive and effective structural programmes. To be effective, structural policy requires co-operation, partnership, and functioning regional administrations.

$E U$ influence on Greek politics was a moot point in that it was supported by the literature (Papageorgiou and Verney, 1992; Ioakimidis, 1994, 1998; Plaskovitis, 1994). I have attempted to establish the type of changes taking place and to analyze how significant this influence is. Further, the exact point of influence was a matter of contention among academics. Ioakimidis (1996) argues that the European Community (EC) did not play a role in the introduction of the Perifereia (Region) in Greece. Similarly, Featherstone and Yannopoulos maintain that the structural policy (the Integrated Mediterranean Programmes) of the EC in the mid-1980s did not seriously

\footnotetext{
${ }^{3}$ I have considered clientelism in the Greek context in depth in my unpublished Ph.D. thesis, please see references.
} 
challenge the Greek centralist tradition. I expected to find that the problems encountered with the Community programmes provided the impetus for Greek decentralization as it is portrayed in Law 1622/1986. Finally, there was also the question of why it took so long for substantial reform to take place in Greece. Was it because the literature was flawed, and that Greece represented the one exception? Or could the argument be made that the Greek system was so flawed that it required additional time for the effect to take place? I found evidence supporting the latter argument. I argue that $E U$ membership provides an impetus for reform, and that this pressure is both of an external and an internal nature. External pressure stems from European membership in general, and from Commission officials in DGXVI in particular. These actors do not have an interest in changing the Greek political system, but they do have an interest in the implementation of $E U$ policies. Although the external pressure is important, in order for true reform to take place, there is a prerequisite of an internal realization of this need for change. The internal element is key here, and much depends on how elites mediate the process of adjustment. Some academics had argued that as long as the careers of the regional administrators were dependent on their obedience to the centre, regional interests would not be satisfied (Featherstone and Yannopoulos, 1995; Verney and Papageorgiou, 1992). I was not convinced that the centre in fact controlled the periphery. I expected to find relationships between central and peripheral actors similar to those which Grémion (1976) found in France. Understanding how the past system functioned was the crucial step to understanding how the more complicated administration would operate. Pressure from within was expected to stem from a new political elite at both the national and subnational levels. This group comprises modernizing elites who have an interest in 
Europe; they have participated in policy-making in Brussels, they have interacted with Commission officials, and would now embrace new ways of thinking. So, this elite will use $E U$ membership to decentralize and modernize Greek politics and internalize Europe.

My work encompasses two broad tests. The empirical test considers administrative reforms in the pre and post 1988 periods. I argue that as the $E U$ structural funds became more comprehensive, both in qualitative and quantitative terms, there was a corresponding increased attempt in Greece to change the system of administration and decentralize. The normative test considers centre-periphery relations. Although there is decentralization in the formal sense, in practice, central elites could have tried to find ways around this. I conducted interviews to determine the extent to which central actors perceived a need for real change and the extent to which subnational actors are gaining a voice. I found that the $E U$ has destabilized the Greek political system, it has destabilized existing centre-periphery relations, and it has encouraged subnational demands for decentralization. The new system is complicated; it is based on a new approach which stresses loosely structured cooperation, in that it is both formal and informal, among multiple levels of state administrations and governments. I conceptualize this new interaction as a Mediterranean Regime where each player needs to exchange resources with the other actors so that as a group, they can secure what individually they cannot. On the one hand, the structural programmes have encouraged the central elite to accept decentralization and to include subnational actors in structural programming. The new system is less centralized; the concern of players is to secure proper implementation of the programmes, and not about power. On the other hand, the decentralized system is operating in the Greek context so there are elements of Greek culture which involve less 
formal, loosely structured interaction woven into it. I label this interaction

Mediterranean because it may be found in other Southern European member states with similar cultures such as Italy and France.

\section{Failed Attempts at Decentralization (i) Europeanization Phase I}

Between 1833 and 1994, there were twelve attempts to establish regional administration; on two occasions, 1843 and 1946, the proposed law was lost on its way from the Ministry of the Interior to Parliament (Introduction of Law 2218/1994). Attempts at even administrative decentralization were modest and were focused on the Prefectures. Indeed, the system of regional and local government, established in 1833, remained relatively stable for the $19^{\text {th }}$ and most of the $20^{\text {th }}$ centuries. With the exception of the left-wing, which saw decentralization as an arena for gaining political voice, in the first two decades following the Civil War (1946-1949), there was not widespread support for decentralization from either the general public or governments (Ioakimidis, 1996). Conservatives were 'Western' oriented in their foreign policy alignment, in their opposition to Communism and Socialism, and in their support of Capitalism. They were not, however, purely modernist because they supported traditional and authoritarian values. Rational inquiry and fundamental freedoms were associated with the Communist party, with rebellion, and with the rejection of established hierarchy (Fatouros, 1993). Indeed, the policy of the dominant right-wing party actually discouraged decentralization.

On the one hand, turbulent internal and external environments did not encourage decentralist politics from central elites. The experience of the civil war had left a 
considerable percentage of the population radicalized by a Communist-dominated resistance to WWII. Despite its military defeat in 1949, the Communist-dominated left remained the third force, and in 1958, it emerged as the official opposition. So, a fear of a Communist uprising made successive governments suspicious of anything involving popular participation, and they kept local government, which was a local bastion for the left wing, as weak as possible. Further, the Macedonian question and the Turkish threat encouraged centralized policies because a weakening of the centre-periphery nexus was considered a threat to the long-term integrity of the country.

On the other hand, Conservative governments attempted to maintain a tight control of the state by using patronage as a form of social control. They offered social security in the form of bureaucratic appointment to those who conformed and were deemed politically fit (Verney and Papageorgiou, 1992). Not surprisingly, the Greek polity was described as having a 'maximum national' and a 'minimal subnational apparatus' (Papageorgiou and Verney, 1992). The lower level, comprising almost 6000 units, was until 1994, the only elected tier of subnational government. Members of municipal and Local Councils were directly elected by means of universal suffrage and secret Ballot. Local authorities had power in matters of local affairs provided that these did not conflict with the Constitution or other legislation. This included responsibility for water supply, drainage, roads, public squares, bridges, parks, sport facilities, markets, kindergartens, urban transport, parking, and pasture lands. They could also provide amenities for tourists, low-cost housing, social services and health facilities, create industrial and commercial firms, and restore historic buildings. Local Councils drew up their local budget, established policy on matters falling under their competence, and 
decided on the local tax rates, duties and dues. ${ }^{4}$ However, all decisions of local governments had to have the approval of the prefect for legality. This provided the centre with control by allowing the prefect the power to delay implementation.

In 1955, Law 3200 allocated Prefectures a separate public works budget, and set up a Prefecture Fund to handle it. Nomarchiaka Symboulia (Prefectoral Councils) were established to discuss prefecture public works programmes, to make proposals concerning the development of the Prefecture, and to consider the functioning of public services and matters involving health and welfare. Councils however, served only an advisory function; they met twice a year and were made up of central civil servants and local government officials. Further, the fact that Councils were headed by a Nomarchis (Prefect), appointed by the Minister of the Interior, who was in charge of the decentralized services of the central ministries located in the Prefectures, meant that they did not pose a threat to centralization. Basically, Prefectures continued to function as decentralized units of central government. ${ }^{5}$

\footnotetext{
${ }^{4}$ They had exclusive taxing rights: slaughterhouses, pasture lands, drinking water, public weights and measures, cemetery privileges, parking facilities, oil lees, unbuilt real estate, beer, advertisements, building licenses, lodgers and hotel guests, benefit from work carried out, town extension, changes in the town plan, lighting, pavements, squares, etc., water supplies and irrigation, use of land and services, and waste disposal.

5 I am not arguing that there was a one-way control where the prefect controlled both the first tier and the prefectoral council meetings. It is interesting that centralization, a Prefectoral system and a clientelist culture, can become mutually reinforcing and produce complicated power relations at subnational levels. On the one hand, clientelism is an attempt of the centre elite to maintain control over the periphery. Since regional representatives are central appointees, clientelism can be a means of curbing subnational mobilization. Alternately, since the locus of decision-making is at the centre state, there is a need for local politicians to find a mediator which can be satisfied through the patron-client tie. From a structuralist perspective, clientelism can be a response to the institutional dependence of subnational levels of government on the political administrative system (Médard, 1981). Further, there is a possibility of a multifaceted, two-level clientelism where the prefect and the local notables are both patrons and clients (Médard, 1981). In the French case, for example, there is a complexity in the political-administrative system which is not easily identified. Grémion (1976) argues that in France, local notables (notables) build a pouvoir periphérique which is a form of power having both an internal and external dimension. There is
} 


\section{(ii) Membership of the EU}

With the fall of the Junta in 1974, the Greek government, under the leadership of

Constantine Karamanlis sought to democratize and modernize the political system. In 1975, a new constitution re-established a parliamentary system which was more democratic than the past. Political elites looked to the French system once again and modeled the Greek state along the French Fifth Republic. This time, however, they sought something deeper than simply copying Western Europe; the political elite of the right wanted to become a part of Western Europe.

The main pro-Europe party was the New Democracy Party headed by Karamanlis. For Greeks in favour of accession, and for Karamanlis in particular, the EC promised both political and economic benefits. Membership was considered to be the way of escaping Greece's dependency on external assistance for financial and foreign policy objectives, and was expected to entrench the restored democracy, secure fundamental freedoms, majority rule, and the rule of law (Kazakos, 1994; Ioakimidis, 1993; and Fatouros, 1993). Further, on a cultural and psychological level, membership offered society a New Megali Idea (The New Grand Scheme, Karamanlis 1991). There were,

not a one-way relationship where the Centre controls the periphery; but rather a mutual dependence.

This type of relationship between Prefect and local elites has not been studied extensively in Greece. Some academics have argued that as long as the careers of the regional administrators were dependent on their obedience to the Centre, regional interests would not be satisfied (Featherstone and Yannopoulos, 1994; Verney and Papageorgiou, 1992). It is true that as long as the careers of the Prefects were dependent upon the Centre, their loyalties remained divided. On the one hand, Prefects were forced to follow the orders of the Ministry of the Interior so they could not stray far from the orders of the centre. On the other hand, prefects had a responsibility of assisting local politicians and were dependent upon the local elite to implement central legislation. This meant that co-operation would be more effective than a topdown attempt to control. I was not convinced that the Centre in fact controlled subnational actors. When I began my research, I expected to find that finer aspects of the Centre-periphery nexus had not been uncovered, and that within the centralized Greek state, there exist power relationships between central and 
however, few political reforms in the years leading up to EC membership and immediately after Greece's accession.

The 1975 Constitution provided for the creation of new levels of government, but the structures of local government did not change. Similarly, PASOK came to power in 1981 with a commitment to decentralize. Although not related to Europe, its manifesto promised to establish new tiers of local government at secondary and tertiary levels, but the reforms of 1982 were very modest. Law 1235 of 1982, on the 'Exercise of Government Policy and Establishment of Popular Representation in the Provinces' attempted to relaunch prefectoral councils. The legislation established the Prefectoral councils on an entirely different basis from that envisaged in Law 3200/55 (Ioakimidis, 1996). The newly reformed Prefectoral Councils were to be a first step towards the creation of new tiers of local government: Article 1 describes the prefectures as 'organs of popular representation'. Councilors were still not directly elected. However, there was a change in their make-up; they went 'from civil-service committees adorned by a local government component' to 'advisory councils representing the various organized interests of the prefecture' (Verney and Papageorgiou, 1992). So, Councils no longer represented an integral part of the central administration. Half the members were local government officials which included the mayor of the leading municipality in the prefecture and two representatives of the Local Association of Local Authorities (TEDK). The other half were chosen by the Prefectoral level governing committees of professional organizations, agricultural co-operatives, chambers of commerce, and trade unions.

peripheral political elites similar to those found in France. I argue later in the paper that I did find evidence of this relationship. 
Councils were to meet twice a month or whenever two-thirds of their members demanded it. Verney and Papageorgiou (1992) note that Prefectoral Councils appear to be 'designed as a local interest group input into the prefecture-level policy-making process.' Councils were still primarily advisory and since most of the bodies in the councils were dominated by the governing party, there was little chance that they would challenge central power (Verney, 1994). Finally, the legislation reinforced the dependency of the prefect by allowing the government to dismiss and appoint prefects at their will. The Prefect presided over the council and had influence over the agenda. Prior to 1982, the Prefect had to approve all decisions within the region, Law 1235 still provided that he/she approve their legality. So, the central government could still use this power to delay decisions.

The political system while problematic in and of itself, was even more dysfunctional in the case of structural programmes which presume a decentralized planning process (Featherstone and Yannopoulos, 1995). The integrative, comprehensive approach of structural programmes requires a well-functioning administration which can co-ordinate the mélange of public and private actors involved in this policy community. Much of this was foreign to Greece's administration and this made membership both a challenge and an opportunity. The Integrated Mediterranean Programmes (1986-1992) stipulated that they be formulated and implemented at the 'relevant geographic levels' (Council Regulation (EEC) 2088/EC). Indeed, it can be argued that the programmes assumed the operation of subnational planning authorities (Featherstone and Yannopoulos, 1995). The problem was that Greece did not have 'relevant geographic levels.' So, the next attempt at decentralization was directly linked to $E C$ structural 
funding. By this time, PASOK had changed its Euro-sceptic stance towards European membership, but this did not translate into real reform. ${ }^{6}$ In 1985 , the country was divided into six geographic areas: the Aegean Islands, Attica, Central and Eastern Greece, Crete, Northern Greece, Western Greece/Peloponnese. These regions were not given any political institutions or administrative structures. They functioned as monitoring committees addressing the progress of $E C$ funding: namely the Integrated Mediterranean Programs (IMPs).

Finally, in 1986, reforms addressed decentralization at both second (prefectoral) and third (regional) subnational levels. Law 1622 entitled Topiki Autodioikisi Perifereiaki Anaptixi kai Democratikos Programatismos (Self-administration, Regional Development and Democratic Planning), provided two means of decentralization: the popular election of prefects and prefectoral councils; ${ }^{7}$ and the division of the country into thirteen Perifereies (administrative regions). In the end, elections were not held at the Prefectoral level. ${ }^{8}$ Indeed, the legislation as it pertained to the Prefectures, was not implemented for eight years at which time a new law was introduced. Regional Secretaries were first appointed in 1988. Regional Councils followed soon afterwards, but they were formed on an ad-hoc basis bringing together central, prefectoral, and

\footnotetext{
${ }^{6}$ PASOK is responsible for implementing the reforms of the 1990s.

${ }^{7}$ If implemented, the legislation would have altered the relationship between the various tiers of administration. Prefects were to remain as organs of the central administration, but their role was downgraded. They were to face two power sources: one from above, because they could be recalled by the Centre at any time; and a strengthened power from below since Prefectoral Councils comprised full time elected officials. Prefects lost control over the agenda, and they no longer presided over council meetings. Councils were now chaired by a salaried president, elected by secret ballot from amongst those council members directly elected by the public.
} 
Commission officials to monitor the implementation of $E U$ structural funds. Regional Secretaries were only given a 'skeleton staff' of administrators recruited from the Offices of the Central Administration (Papageorgiou and Verney, 1992). Regions were intended to co-ordinate planning and to monitor the regional budget. The Perifereia however, was not given political institutions, administrative structures, or a working budget. Not surprisingly, the Perifereia could not properly perform its designated responsibilities (Papageorgiou and Verney, 1992).

\section{Europeanization Phase II \\ (i) Metarithmisis in the 1990s: the Decentralization Laws}

Laws 2218, 2503, and 2647, outlined below, established two regional tiers, one administrative, the other political. The 13 Perifereies of the 3 rd tier are deconcentrated administrations, these are a new type of Regional Prefecture. Legislation provides that the Perifereies and the General Directorates of the Perifereies be organized into functioning administrations, with their own personnel and their own responsibilities. On paper, they have been given administrative responsibility particularly in the area of regional development. There is also a transfer of powers from the Central Administration to the 13 Regional administrations. The end result, as stated by the Minister of the Interior is 13 Mikres Kiverniseis (Small Governments) (Ethnos, 10 February, 1997). The elected Prefecture of the $2^{\text {nd }}$ tier becomes a new subnational government. Direct elections of the Prefects and Prefectoral Councilors took place for the first time in October 1994. Prefects in particular gained extensive powers: they have elected status

\footnotetext{
${ }^{8}$ In March of 1990, the 'ecunemical' government (co-operation between PASOK, the Nea Democratia, and Synaspismos) legislated for elections to be held in October 1990, but when Nea Democratic came to power
} 
and considerable resources at their disposal. They have offices, civil servants, and responsibility in licensing and commissioning of local development projects.

My initial analysis of the decentralization laws led me to conclude that in the period prior to 1994, there were small, but significant changes focused on the Perifereia. In 1994, the legislation equally addressed the Prefectures and the Perifereies. In the post-1997 period however, the focus shifts to the Perifereia. So as the regional tier increases in importance the Prefecture decreases. This shift in emphasis corresponds to a shift in subnational responsibility in the area of structural funds. That is, Prefectoral and regional actors gain access to Structural Policy through the Regional Council and Regional Monitoring Committees. Indeed, the Regional Council is described as the 'choro ekfrasis' (place of expression) of local governments and the representatives of the productive classes (The Citizen's State, 1997). I argue later in the paper that this creates tension between the $2^{\text {nd }}$ and $3^{\text {rd }}$ tier actors. I also argue that this creates a complicated inter-connectedness between the various levels because actors realize that if they do not co-operate, they will lose the opportunity to participate and to influence policy.

\section{Law 2218/1994 Establishment of Prefectoral Self-administration, modification of provision for first level self-administration and the Perifereia}

Article 1 establishes Nomarchiakes Auto-dioikisis (Prefectoral Governments) as the '2nd level organization of local self-government.' Prefectoral Council members are directly elected by universal and secret ballot every four years at the same time as the municipal elections (Article 5). There are similar restrictions for candidates as Law 1622, 
candidacy to the two levels of local self administration is not permitted, and re-election of the Prefect is permitted only once. So, the Prefect can only run for two terms. He/she is elected candidate Prefect of the winning coalition. Prefectoral Governments receive revenues from duties, taxes, entitlements, and contributions; income from the exploitation of property; specific annual economic reinforcement of the tactical budget for covering the costs of administering state responsibilities which have been transferred to the NA; and central independent resources. The Prefectoral Council meets at least once a month, or more frequently if one third of Council Members or the Prefect requests it. Each Prefectoral Council is responsible for the regulation of the matters of the Council, regulation of matters of the Prefectoral Committees and the organization of the offices of the NA. The Prefect is the representative of the Prefectoral government. He/she carries out the decisions of the Prefectoral Council and is responsible for the everyday functioning of the prefectoral government. Prefects pronounce all acts that are nonregulatory in character and they execute the decisions of the Prefectoral Council and the Prefectoral Committees.

Part III of Law 2218 re-addresses the Perifereia, marking the first significant steps to creating a proper area of regional state administration. Article 49, entitled 'Administrative Division of the State', reads:

the Perifereies which the country is divided in accordance with Article 61 of Law $1622 / 1986$ for the planning, programming and coordination of the regions' development are also administrative regions and constitute an administrative unit of the state.

Following Law 1622, the legislation establishes in every Perifereia a Regional Council comprising a Perifereiarchis (Regional Secretary) of the Region as chair; the prefects of the Region (now directly elected); a representative from every local union of 
municipalities and communities (TEDK) which are in the Perifereia, who is elected along with a representative from the governing committee of the TEDK; one representative for each Regional Organization such as the Chambers of the Productive Sectors, the Technical Chambers of Greece, the Geotechnical Chamber of Greece, and the Economic Chamber of Greece. Representatives of various Ministries are permitted to attend meetings, but are not allowed to vote. The Regional Council is convened with the decision of the General Secretary of the Region. Effective January $1^{\text {st }}, 1995$, the Regional Council has the powers outlined in Article 63 of Law 1662/1986.

Further, in the headquarters of each Perifereia there is introduced a Perifereiako Tameio Anaptixis (Regional Development Treasury) which is supervised by the Minister of the Interior. The Treasury is an organ of programming and development and acts in accordance with the decisions of the Regional Council. The Treasury can undertake all the programming measures of the Perifereia within the framework of the European development. So, unlike Law 1622, there is reference to the EU. The Regional Secretary is President of the Treasury; he/she represents the Treasury in Courts, carries out the decisions of the Treasury, and orders the collection of funds for the Treasury.

The position of the Regional Secretary is modeled on that of the Prefect in the pre-1994 period, but the former has less powers. The Regional Secretary takes on a supervisory function. Article 18 states that 'all acts of the Prefectoral Council, the Prefectoral Committee, and the Administrative Councilors are forwarded to the General Secretary of the Region within 5 days of the meeting along with a copy of the certificate of publication.' Within 5 days of receiving the act, the Regional Secretary must send decisions/acts that he/she considers are not legal along with explanation to a tri-member 
committee. This committee is established in every Prefecture. The committee belongs to the Ministry of the Interior. It is convened at the request of the Regional Secretary and by the invitation of the Chair. Its purpose is 'to examine the legality of the acts of the Prefectoral Council, Prefectoral Committee....which are referred to the committee by the General Secretary of the Region.' Further, in matters involving the Treasury of the Prefecture, such as the collection of revenue, the prefectoral authorities must provide any information which the Regional Secretary requests. If it is found that the Prefect and members of the Prefectoral Council have committed a serious violation of their duties, or have exceeded their powers because of fraud or serious oversight, the Regional Secretary can impose the administrative sanction of suspension and allowance of up to three months.

\section{Law 2503/1997 Administration, Organization, and Stelehosis of the Perifereia}

Whereas Law 2218 addressed both the Prefectures and the Perifereies, Law 2503 is focused on the Perifereies. Indeed, Law 2503 makes the region a devolved administrative entity with its own organization, its own budget, and its own staff. Article 2 provides for the transfer of every type of personnel of the Ministries which placed Directorates in the Region. Provision is also made to staff the regional administration with qualified personnel.

The 'instruments' of the Perifereies are the Office of the Regional Secretary and the General Directorates of the Perifereia. Article 2 provides that in every Perifereia there is a General Directorate which is called the Directorate General of the Perifereia (Geniki Diefthinsi Perifereia's) and a Director General who is the supervisor. The 
General Directorate is composed of all the Directorates and the independent sectors and offices of the Regions which have a seat within its administrative limits. ${ }^{9}$ The functions of the Director General of the Region are purely administrative. Regional power rests with the Regional Secretary who is 'the highest regional official'. The Regional Secretary 'proistatai' (supervises) all the offices of the Perifereia, directs, coordinates, supervises and examines the activity of the offices and the officials of the Perifereia. $\mathrm{He} / \mathrm{she}$ also has exclusive responsibility which has been entrusted or transferred to the offices of the Perifereia along with every other responsibility which the law has provided or has entrusted (Article 1). Among his/her responsibilities/powers is to supervise (epopteui) and monitor (eleghi) the local self-administration which includes the municipalities, communities, prefectoral self-administration, and their legal personnel (Memo from the Ministry of the Interior, 1999). Finally, the Perifereia is given resources of its own. Article 4 entitled the 'Collective Decision of the Works of the Perifereia,' places the General Secretary of the Region as the chief director of the budget for his/her region. The legislation states that as of 1998, the MNE issues Sillogikes Apofaseis Ergon Perifereieas (SAEP). These are works of a regional character contained in the Budget of the Public Investments.

\section{Law 2647/1998: Transfer of Powers to the Perifereies and Self-administration}

This legislation represents a significant step towards a more comprehensive administrative decentralization. Article 1 outlines the powers which the Ministries

\footnotetext{
${ }^{9}$ The Directorates are as follows: Planning and Development; Health and Welfare; Public Works; Monitoring of Construction of Work; Monitoring of Maintenance of Work; Environment and Planning; Forests; Agricultural Development; Self-administration; Administration by the self-contained sectors ,
} 
devolved to the Regions and Prefectures, and provides for additional transfer of personnel from the $1^{\text {st }}$ and $2^{\text {nd }}$ tiers of local government to the Perifereia and from the Perifereia to lower tiers. Provision is also made for a further transfer of powers from the following Ministries to the Prefectoral level: the Ministry of Development; the Ministry of Education and Religion; the Ministry of Agriculture; the Ministry of Health and Welfare; the Ministry of Transport and Communication; and the Ministry of Public Order. However, as was the case with Law 2503, devolution is once again focused on the Perifereia. The Ministries of the Interior, Public Administration and Decentralization; Development; Environment and Public Works; Education and Religion; Agriculture; Labour and Social Security; Health and Welfare; Culture; Commerce and Shipping; and Transport and Communications; all devolve administrative powers to the Perifereies. Further, certain responsibilities are divided or shared between the Perifereies, Prefectures, and the Central Administration.

\section{(ii) Explaining the Enigma}

There is a connection between $E U$ membership in general, and structural funds in particular, and the reforms. This argument was supported in all of the literature I had studied prior to undertaking my own research. Indeed, the numerous attempts to reform the political system in the last twenty years supports this argument. There was, however, a discrepancy between the support for European integration and the resistance of successive governments to remove some of the negative aspects of the Greek political system. Unlike British governments which feared devolution upward to the $E U$, and until 
recently, downward to the regions, the two major Greek political parties support European integration. So, it is somewhat of an enigma, that until recently, they had resisted decentralization and modernization. Indeed, the political elite had for a long time understood that in order to take advantage of EU membership, there was a need for administrative reform (Interviews with Central Officials).

My explanation for the discrepancy is that Greece experienced a delayed impact. As structural policy evolved, there was a corresponding time-lag before the policy would affect the internal functioning of the Greek political system. Centralization was so entrenched in Greece that the Greek elite needed more time to adjust. Further, the problems of the administration and over-centralization had to be experienced so that the political elites could come to appreciate the shortcomings of the Greek system. Time was also needed for a learning process to take effect on the political actors. Unless there is an internal acceptance that there is a problem, there is little possibility of real change. Greeks want to be their own masters. To change on one's own accord is one thing, to be told to change is quite another (Interviews with politicians and upper level civil servants).

I tried to establish at what point the influence of $E U$ structural programmes had a real effect on the Greek actors. This was important because it helps place the reforms in a time context. This was also important to determine since it was greatly debated among academics. Featherstone and Yannopoulos (1995) argue that the IMPs did not seriously challenge the Greek centralist tradition. Similarly, Ioakimidis (1996) suggests that the European Community did not play a role in the development of Law 1622/1986 because it did not have a coherent regional policy prior to 1988; PASOK was Eurosceptic at the time; and Law 1622 makes no reference to the Community. Further, one could argue, 
that this decentralization was simply the realization of PASOK's pre-electoral promises. The Law entrusted the Regional Councils with seven functions, but it does not refer to the design or to the implementation of Community policies. On the other hand, the creation of the regions was motivated by the problems encountered with the IMPs. I argue that problems encountered with the IMPs provided an impetus for Greece to establish a level of regional administration. The IMPs necessitated a level of regional administration, and their successors, the Operational Programmes of the First and Second CSF, have been the direct cause of the establishment of regional institutions. Although the IMPs were not as comprehensive regional programs as the $R D P s$, they were nevertheless regional funds (Papageorgiou and Verney, 1992; Verney, 1994). Further, the initial responsibility of the Perifereies was the monitoring of $E C$ regional programmes. Also, by the mid-1980s, PASOK had undergone a remarkable change in its position towards the EC (Featherstone, 1994). Unlike the Prefectoral element of Law 1622 , the regional aspect of this legislation as it applied to the third tier of decentralization was partially carried through. This is of great significance and points to a connection to $E C$ programmes. My argument is that the regional aspect of Law 1622 was operationalized because of the regional programmes. The postponement of elections at the second level cannot be explained simply by stating that Nea Democratia favoured centralization. Indeed, PASOK was in power for three years following the introduction of Law 1622 and had sufficient time to carry out the reforms. Further, elections at the Prefectoral level were not a response to integration; rather, they were partly a response to the political promises of $P A S O K$, and partly a response to the general decentralization taking place across much of Europe (Spanou, 1998). The Perifereia however, was a 
different matter. Its institutionalization shows the awareness on the part of Greek politicians of the need of a regional level in the management of regional programmes (Christofilopoulou, 1996). So it can be argued that the EC played a key role in 'encouraging' the PASOK party to introduce regional reforms (Featherstone and Yannopoulos, 1995; Verney, 1994).

It can also be argued that as $E C$ structural funds became more comprehensive, both in qualitative and quantitative terms, there was a corresponding increased attempt to decentralize. After a slow start, reforms have taken on a momentum. Further, it can be argued that over time, the political philosophy of partnership and subsidiarity 'challenged centralization' (Featherstone and Yannopoulos, 1995). So the structural funds have had a marked impact on regional infrastructure and have played a role in strengthening administrative decentralization (Plaskovitis, 1994). These reforms represented a significant step towards decentralization; and they provide 'a good example of institutional reform encouraged by Brussels, rather than emerging exclusively as the outgrowth of internal political process' (Papageorgiou and Verney, 1992; Plaskovitis, 1994; Verney, 1994). The Greek central administration had been 'forced' to formulate policy within a coherent set of programme objectives and more importantly, it had been asked to share this responsibility with subnational authorities (Ioakimidis, 1994). Evidence also suggested that $E C$ policies create an internal pressure for greater administrative decentralization to promote democracy and efficiency (Featherstone and Yannopoulos, 1995). This is of great significance because external pressure alone cannot ensure comprehensive and meaningful reforms in politics.

I argue below that there are comprehensive legislative reforms in the 1990s, and 
more importantly the nomimotis (legal state) approximates the pragmatikotis (real state) in other words, reforms are not 'empty shells.' In Phase II of Europeanization, Greek politicians have questioned assumptions held in the previous phase concerning the centreperiphery nexus and the practice of clientelism. I am defining Europeanization as a process of adjustment which domestic actors (society and/or political elites) perceive as beneficial and necessary. Europe is still connected with modernization, but Europeanization in this phase stresses a flexibility and an appreciation of existing traditions and contexts. Unlike past reforms, the aim of the political elite is not a complete metamorphosis, but a reform of the system in such a way that it is prosarmosmeno (adapted) to the Greek context and culture. This is a pragmatic response to the problems plaguing Greek politics. If the emphasis is on adjustment, an anamorphosis, and if the elite is in favour of change, then there is a strong possibility of successful reform.

\section{(iii) Ta politica}

Much is dependent on how the elites mediate the process of adjustment. Considering the past failures at reform the real test was to see how the politics was being played and how the system was functioning. I use data from interviews at the national, subnational, and $E U$ levels to detect these finer changes. I consider how the actors are playing the game by analyzing the relationship between the centre and the periphery, and the relationship between the Perifereia and the Prefectures. This determines whether there is a change in the ideologies of the players and whether there are new ways of thinking at both national and subnational levels. This is important because it helps understand the 
rationale behind the reforms. For real reform there must be two sets of modernizing elite: one at the centre, so that the legislation is passed and there is a real devolution of power to the periphery; the other in the periphery, because these are the individuals who are given the devolved powers.

On paper, the powers of the Greek central administration have been restricted and it can be argued that the state is no longer centralized. This is largely an administrative form of devolution. Although there has been political decentralization which has favoured the Prefecture, the most significant reforms are focused on the Perifereia which has been operating as 'a decentralized unit of administration of the State' as of September $1,{ }^{\text {st }} 1997$ (Memo from the Ministry of the Interior, 1999). On the one hand, one can argue that these are significant steps for a country with such a centralist tradition. On the other, one can also argue that although there may be decentralization in the formal sense, in practice, the centre may try to find ways around this so that the structures become 'empty shells.' So the question is: How is the Greek administrative model operating in practice? This was answered by a normative test which is based on the in-depth findings of my interviews of central, subnational, and Commission officials. From these interviews I attempted to understand the finer functioning of the political system and offer some conclusions on how 'ta politica' are being played. I consider the role of subnational actors and try to establish if in fact there is a subnational mobilization capable of counteracting central pressures. Approaching the problem from above, I consider if central elites are changing attitudes towards elite subnational participation. 


\section{A new role for subnational elites}

The reforms represented a significant step towards decentralization, and they provide 'a good example of institutional reform encouraged by Brussels, rather than emerging exclusively as the outgrowth of internal political process' (Papageorgiou and Verney, 1992; Plaskovitis, 1994; Verney, 1994). The Greek central administration had been 'forced' to formulate policy within a coherent set of programme objectives and more importantly, it had been asked to share this responsibility with subnational authorities (Ioakimidis, 1994). However, evidence also suggested that EC policies create an internal pressure for greater administrative decentralization to promote democracy and efficiency (Featherstone and Yannopoulos, 1995). This is of great significance because external pressure alone cannot ensure comprehensive and meaningful reforms in politics.

Although I was told that some officials in the Central Ministries do not want to devolve responsibility and lose powers, there is a greater consensus than in the past of a need to carry out some type of decentralization (Interviews with MNE and Interior Ministry). A senior civil servant who was part of the team responsible for framing the decentralization laws of the 1990s noted that the Greek administration is being pushed by the Commission. However, Greek officials see a need for reform. They realize that everything cannot be controlled by the centre (Interview with Senior Officials in Interior Ministry). Officials in the Central Ministries did not have a clear understanding as to what was happening in the regions; decentralization was needed because 'only regional actors know the region's needs.' Regional authorities bring a practical experience to the policy-making process which is much needed when framing and implementing regional 
programmes (Interviews with Officials in MNE). Further, the system of administration had to change in order to deal with the challenges of modern times. The argument was that the centralized state had to change and it had to change immediately because 'this model of the state had completed its cycle' (The Citizen's State, 1997). So, the benefits of decentralization are beginning to be realized by central politicians and administrators who perceive the need to co-opt the regions as partners (Interviews with senior Officials in Central Ministries). While the reforms may have happened in the absence of $E U$ membership, the 'EU drove the current reforms and has penetrated them' (Senior Official in Interior Ministry). I was told that times are changing and the anagkes (needs) are changing. The anagky (need) equals membership of the $E U$ (Interviews with Upper Level Civil Servant in Central Macedonia, West Greece; Interviews with Senior Officials in the Ministry of the Interior; Interviews with Officials in the MNE).

Regionalization was a top-down response to the changing demands on the political system. It was put in place without a direct link with regionalism, that is, without demands for autonomy impelled by cultural or ethnic factors. The argument of central elites is that development must be from the bottom up, and there must be respect for the principle of subsidiarity (The Citizen's State, 1997; Interviews with Upper Level Civil Servants). The argument being that one can kiverna (govern) from afar, but one cannot dioikei (administer) (The Citizen's State, 1997). So, the state entrusts the exercise of important powers of a regional character to the regional state organs or to organs which are elected by the citizens of the local society (The Citizen's State, 1997). The state is brought close to the people and decisions are made close to the problems, so that the citizen does not feel that issues are dealt with by distant, anonymous organs who do 
not, and cannot have an understanding of their problems (Interviews with Central Officials).

The reforms involve two strands: a political decentralization through the creation of a level of government between the $1^{\text {st }}$ tier and the centre and a de-concentration of administrative responsibilities with an aim of modernizing the state at the level of the Perifereia. Elections at the prefectoral level were in theory an important step for devolution. The focus of the reforms, however, is on the Perifereia. The anavathmisi (empowerment) of the regional organization of the country and the orthologiki katanomi (rational distribution) of powers between the centre and the Perifereia make up the necessary proipotheseis (prerequisites) for the development of a modern, apotelesmatikio (effective), state (The Citizen's State, 1997). This ‘secures the democratic modernization of our political and administrative system' (The Citizens' State, 1997).

The end result is that the state is no longer centralized and the reforms are not 'empty shells.' The Perifereies are administrative units, but they are rather independent of the state. Each Perifereia is a unit of administration having power that is exercised by its civil service within its geographical area including civil servants operating within the prefecture. Powers are moving to the Perifereia, but the state has also moved to the Perifereia (Interviews with Central Ministries). That is, the task given to the Regional Council to decide is quasi-political because representatives from the first and second tiers are elected at their respective jurisdictions, while the tasks of the decentralized Ministries to implement are purely administrative. The Perifereia gains more than its previous programming role; it has the dinatotita (power) to implement national and regional plans. It is a new administrative unit capable of programming, designing, coordinating and 
applying the policies of economic, social and political development. It unifies the disperse cross-Prefectoral offices of the ministries into a new organization structure for the improvement of its coordinating and programming role (The Citizen's State, 1997). It becomes a framework for the effective exercise of the transferred powers from the central administration; securing unhindered cooperation and productive cooperation with the central administration for national programming (The Citizen's State, 1997). So it is the syndetico kriko (connecting link) bridging the central administration with self-governance (The Citizen's State, 1997; Interviews with Central Administration).

It appears that the central administration is accepting the need for administrative devolution to secure a level of administration capable of addressing regional policies and capable of adapting and implementing central regulations as it sees fit. Further, it is administrative devolution that is being stressed. The focus on the Perifereia is interesting. On the one hand, the regional tier is seen as a more appropriate level for dealing with regional issues (Interviews with Officials at Central and Subnational Levels; EU Commission). On the other hand, the Perifereia poses less of a threat to central powers than the elected Prefectures do. This is where ta politica were expected to have a decisive role. Accepting decentralization was the first step to reform. The second step is the actual implementation. The question was how the new administration was functioning, and how they were using their new powers. So, I set out to determine how the elites were playing the game.

Although the literature on the 'Europe of the Regions' focuses on regions operating at supranational levels, there is an internal dimension to territorial politics which should not be overlooked. Jeffery (1997) used the concept of 'European domestic 
policy' to describe the German domestication of European politics. Applying this reasoning to a decentralized Greek system, domestication could involve a reconfiguration of clientelism in the periphery. Taking France as example, the decentralization of the 1980s complicated the system of corruption by adding an additional layer of administration. In Greece, the more layers of government, the more civil servants with contracts, favours and rousfeti to distribute. So the system could absorb Europe and use $E U$ funds to extend the practice of clientelism in such a way that the old system, the 'Hellenic' mode of operation, reconfigures across multiple levels.

Alternately, in time, a new type of political system could emerge which is both modern and decentralized. Over time, clientelism can be 'reinterpreted' and 'updated' (Piattoni, 1997). Piattoni (1997) also argues that change in the type of clientelism can take place if a system is subject to external shocks, if there is a change in the strategy of patrons or if the pressure from clients changes. Since clientelism has persisted for centuries in Greece, in order for it to change, there must be a strong impetus. My hypothesis was that membership of the $E U$ provides this force because it provides Greek political elites with the incentive to change the dynamics of the system. When I started my research, I expected to find that $E U$ membership had destabilized centreperiphery relations and had enticed subnational actors into action. I expected that a bottom-up analysis would reveal a new set of elites at the subnational level that corresponded to the set of elites at the national level. An old group was expected to be found primarily at the Prefectoral level and a new group of modernizing elites would be forming in the Perifereies. The former set of actors would be more traditionalist; they are interested in decentralization, but will use new powers and funds to further their 
clientelist practices. Preliminary research, however, also indicated that there was a learning process from the interaction with other member states and a belief that Brussels has a 'pot of gold' which would entice subnational actors, mobilize them to change subnational politics, and help them contemplate breaking away from their dependence on Athens. Papageorgiou and Verney (1992) found that in a short period of time, subnational actors went from using Athens as an interlocutor with the $E U$ to seeking direct links with Brussels.

So, the political environment was very encouraging for those wanting change. I believed that this new elite has an interest in modernization and decentralization and that these actors may establish a new type of politics which is not based on clientelism, at least not a clientelism which works to the detriment of development. My hypothesis was that the changed structure and changed politica would alter clientelism; it would disappear as a method of bureaucratic appointment, but it would remain, at least in the short run, as a method of interaction between actors of policy communities. Patronclient ties can be used to different ends, so the role of agency is important here. I borrow Stone's conception of a regime which can be useful when conceived as a structure and an analytic framework. Keating (1997) argues that the concept of regime can be used to analyze a set of arrangements through which policy decisions are made involving political, economic, and social actors who are devoted to economic development in a specific region. There was, however, also a question of context. Stone admits that his notion of regime while applicable to American politics may not be suitable in other contexts. This raises particular concerns when analyzing politics in Europe, and southern Europe in particular. I argue that in the latter case it may be suitable to 
consider the concept of a Mediterranean Regime which entails a method of interaction within the policy community or coalition which has elements of clientelism. The assumptions are that there is a culture which has distinctive characteristics which can be labeled Mediterranean; that in the context of politics this involves personalistic, informal, ad-hoc, methods of operation; and that this interaction resembles a regime in that actors come together to secure collectively what they could not do individually. I look for the players involved in EU Structural Policy-making, consider how they interact, and what they aim to achieve. I expected to find that in Greece, with decentralization, there is an empowerment of peripheral actors, their conversion into partners, and the emergence of new forms of elite co-operation which resemble my conception of a Mediterranean Regime.

What I found was that there has been a change in centre-periphery relations which was substantive. At times, this change was also symbolic and informal. Here, I crossverified my findings from interviews with interviews at other levels. So, I considered what Central officials stated within the context of what subnational actors were claiming. I also considered what subnational actors were saying by cross-checking responses at the other subnational level. So, responses for the Perifereies were cross-checked with the Prefectures and responses of the Prefectoral actors were cross-checked with respondents from the Perifereies. Finally, when possible, I cross-checked all responses with officials in the EU Commission DGXVI who were involved with the Greek Programmes.

\section{Relations between elites}

It was very important to establish the relationship between the new tiers of subnational 
actors because this would lead to conclusions about the politics between the centre and the periphery. In terms of epiroi stin Perifereia (influence in the Perifereia) most of the interviewees argued that the Regional Secretary exercised more powers than the MP and the Prefect exercised less powers than the MP. Further, the Regional Council was believed to have less influence than the Monitoring Committee of the CSF. Elections may have taken place in the Prefectures, but not much came of it (Interview with Interior Ministry). Indeed, the position of the Prefect apodinamonetai (is losing power) while the Regional Secretary is gaining power. The "head of each of the 13 Perifereies is the Regional Secretary; he/she is the Highest Organ of the State, having general powers, he/she is the Representative of the Government and is responsible for exercising the Government's Policies for matters concerning the Region' (Memo dated 4 February 1999 from the Ministry of the Interior to the Ministries). The Regional Secretary is now getting the power of the Prefecture, he/she is representing the kratos (state) (Interviews Upper Level Civil Servants in Ministry of the Interior, 1999; Interview with Commission Officials 2000).

I expected to find two types of tensions: one tension which results from a clash between the new and old elite; and a second tension which results from a power struggle between the $2^{\text {nd }}$ and $3^{\text {rd }}$ tiers. The explanation for the former tension is that the Regional Secretary eleghy (supervises/monitors) the clientelist practices of the Prefectures. The explanation for the latter tension is that Prefects believe that because they have achieved elected status, power should go to them under the rules of subsidiarity. What I found is interesting. The Regional Secretary does not have the power over the Prefecture that the Prefect once had over the first level. All he/she can do at present is set up an Epitropi 
(Committee). Nevertheless, the Prefect would prefer that there was no Regional Secretary. Indeed, there are times when there is an entasis (tension) between the second and third tiers, the Interior Ministry confirmed this, the Regional Secretary confirmed this, the Prefects after probing confirmed this, and Commission officials confirmed this.

I also expected to find cooperation. I found a more complicated version of this symbiosis between the Regional Secretary and Prefect in the post-1994 period. Indeed, perhaps the most interesting evidence of an intellectual diffusion resulting from $E U$ interaction is the fact that the principle of epikourikotita (subsidiarity) has been adopted in the political lexicon. It is being used by actors at all political levels: central, regional and prefectoral elite as they attempt to claim powers. This is remarkable considering that the principle was, until recently, a foreign concept to Greek politics.

Tension from this power struggle was also expected to be a result of the mobilization of subnational actors at the Prefectoral level. The fact that the Regional Secretary is there na eleghy (to supervise/monitor) the Prefectures creates problems because the 'Prefect does not want anyone over his/her head' (Interview with Central Administration and Commission Officials). Central civil servants had noted that a strain was present between Regional Secretaries and Prefects and that this occurred across all Perifereies.

When I probed a little, I found this strain. I determined that Prefects realize that in order to operate in the system of $E U$ policy-making, they must possess constitutional status and economic resources. So they are determined to retain their newly acquired areas of responsibility. Prefects also argued that the Perifereia is good because rather 
than having to go to Athens, 'Athens' is there so that problems are resolved more quickly and more efficiently. The Prefects however, use whatever relay they can: the Regional Secretary, the Ministries, and the Commission. There is evidence that they intervene for the good of their Prefecture and pressurize their Regional Secretary. Sometimes, Prefects go directly to the centre. They claimed that there were occasions when this was quicker than taking the regional route. There was also a fear among some Prefects that the Regional Secretary will favour one Prefecture over another (Interview with Ministry of the Interior). So, going directly to the centre may be an option when they are not pleased with the results they achieved with the Regional Secretary and believe they were treated unfairly.

\section{Resolution of tension: a movement to co-operation and the emergence Mediterranean Regimes}

Although there is tension which results from the frustrations facing Prefects, officials noted that there is not as much concern with power; in the past, power relations were more important. Approaching the problem from below, a voice within the Regional Council and Monitoring Committee is better than no voice at all. Approaching the problem from above, the Central administration is increasingly valuing the input of Subnational actors. So now, the stress is on building a consensus to secure common interests (Interviews with National, Subnational and Commission Officials). Indeed, often there is not a defined separation of responsibility in the implementation of $E U$ regional programmes. Development itself is defined as reaching the goal of programmes through co-operation and partnership; the emphasis is on consensus of all involved 
(Interviews with Officials in MNE; Officials in Subnational Administrations; Interviews with Commission Officials).

Papageorgiou and Verney (1992) had found that the role of the Regional Secretary was important. In cases where the Regional Secretary took an active interest in the formulation of the RDP, and exercised the right to hold regional conferences and information meetings, the end result was much closer to an integrated plan than was the case with the IMPs. This potential role of the Regional Secretary was commented on during the interviews I conducted in West Greece. The Regional Secretary takes on the role of mediator; he/she also speaks on behalf of the Prefecture. Everyone has a voice through the Regional Secretary. For example, even representatives from the MNE discuss issues with the Regional Secretary and the Regional Secretary then speaks on their behalf during meetings of the Monitoring Committees (Commission Officials). . The role of the Regional Secretary, however, is not that of the Prefect of the past. There are more actors involved, and the policy process has become more integrated. On the one hand, since the Regional Secretary is a political appointee, his/her presence may be a means to curb subnational actors at the Prefectoral level. Alternately, the locus of decision-making is now moving to the Perifereia so there is not as great a need for a mediation role as there was in the pre-1994 period. Instead of mediation, there is more direct participation and cooperation between all three subnational levels. Regional Secretaries want good relations with actors at all levels because each needs the other. I was told by numerous officials that Regional Secretaries who have had experience in local politics know that they must co-operate. They see the need for symbiosis. Indeed, you cannot antagonize other players. Co-operation and consensus-building between the 
Regional Secretary and the Prefect is a pre-requisite for successful regional development (Upper level Civil Servants from Central Macedonia and West Greece). I established that there was dialogue between actors before final meetings of the Prefectoral Councils and the Regional Councils. So in many cases, the meetings are tipika (a formality) because agreement has been reached before hand. There is also co-operation in the Regional Council. In the late 1980s, Verney and Papageorgiou (1992) found that 'mediating the conflicting interests of the various groups of the Prefecture' was the second lowest priority. The authors argued that 'the concept of politics as mediation between different interest groups has not taken root to the same extent as in other West European countries.' Although more research is needed, my interviews have led me to conclude that this is beginning to change. Actors in the Regional Councils stressed the importance of reaching consensus and intervening to try to find solutions when the interests of two groups conflict. There are also a number of informal changes. New channels of communication have been opened between the centre and the periphery. Communication has increased between the MNE and subnational authorities and has decreased between Interior Ministry and subnational tiers. New networks of communication have also emerged between the $E U$ and subnational levels. Subnational authorities have found a strong ally in the Commission in particular as they attempt to influence policy-making and secure their place at the policy-making table. Finally, there is a certain confidence developing at the subnational levels. Ioakimidis (1998) argued that there is a self-assertion of the region which has changed the Perifereia vis-à-vis the centre. In the past, subnational actors considered the centre as something 'superior' which should be copied, but now, regional administrators are gaining confidence in their 
abilities. This may help in encouraging subnational mobilization.

I determined that the new system is very complicated; it rests on cooperation between the multiple levels of state administrative agencies and governments. Indeed, it can be argued that European integration can encourage policy-making to move into networks. Network analysis seems particularly appropriate with regard to European policies because of (i) the weakness of the European bureaucracy which necessitates the involvement of multiple levels of government and leads to interaction between European, national and subnational administrations; and (ii) the fact that implementation of European programmes relies on co-operation between private and public bodies (Balme and Jouve, 1996). In Greece, this network comes together at the level of the Perifereia.

Central, Regional, and Prefectoral actors become intermeshed so that the distinction between levels loses importance. Sometimes the Perifereia has responsibility with the centre; at other times the centre may pass to the Perifereia (Interviews with MNE Officials involved with the Programmes since IMPs). I found that actors at all levels are playing the game with caution; that each level is suspicious of the other. Everyone, however, a few albeit grudgingly, sees the need for co-operation and symbiosis. Indeed, at present, cooperation seems to be their only vehicle at succeeding and everyone seems well aware of this. At the centre, there is a new elite which sees a need for subnational partnership. There is also a small percentage of old elite who are concerned about losing power to subnational actors. At the periphery, there is again a split where Prefectoral actors are suspicious of the centre who they see as trying to keep control; and regional actors who are suspicious of Prefectoral actors who at times they see as trying to get control for clientelistic/traditional purposes. Both Regional and 
Prefectoral authorities, however, know that they are dependent on one another for successful regional development. Actors realize that studies, analysis, and cooperation from authorities at both levels are needed for a comprehensive development. Further, their voices are heard as 'one' through their decisions in the Regional Councils and Monitoring Committees. Finally, interest groups are perceiving a change in power and are lobbying all levels of the administration. This branching out of organized interests may also be a result of the state's realization of the importance of the private sector in implementing structural policy. The argument is that in order to succeed, there must be input from all affected authorities. Private sector actors bring new life and new ideas to the process because they are not as stagnant as the public sector. My research found that all actors, including interest groups, try to resolve any disputes between groups in the Councils. Interest group representatives from the private sector also use whatever relay they can. They lobby their own Prefect and other Prefects of their Perifereia and the Regional Secretary prior to Regional Council meetings. ${ }^{10}$

I found that with decentralization, there is an empowerment of peripheral actors, their conversion into partners, and the emergence of new forms of elite co-operation which resemble a Mediterranean Regime. Policies facing the Greek administration are complicated and this has created an understanding that power relations between players have changed. It is not a question of who has power over whom, but whether or not

\footnotetext{
${ }^{10}$ In France, societal groups find it still more efficacious to link up with state field services (agriculture, environment, employment) or secondly with other local governments (social policies in departments, housing and urban policies in cities) than with region government (Balme and Jouve, 1996). Indeed, 'a hypothesis can be put forward that, in the future, the emergence of the regional councils as a meso-level of government will be largely influenced by their ability to 'regionalize' public and private interests and to build institutions around which 'political regimes' (Stone, 1989) founded upon alliances between certain
} 
actors can secure their ends. This often involves informal arrangements between many levels of administration. The Greek model of territorial integration has been greatly altered and centre-periphery relations have been modified. In the past, the central elite were very concerned about losing power to the subnational tiers. In the late 1990s, however, there has been a weakening of the control of Athens as a political centre over the Perifereia. So, subnational actors have entered the game. There is also cooperation and consensus-building where the new rationale of the centre appears to be as follows: 'we will do whatever is needed to ensure Greece's political and economic success, since this entails co-operation with subnational actors, then co-operate we will.'

\section{Conclusion}

It can be argued that the Greek government has an interest in administrative devolution because improper implementation would jeopardize Greece's prospects for convergence with the economies of other member states (Papageorgiou and Verney, 1992; Ioakimidis, 1996). This type of devolution would transfer administrative responsibility to the Perifereies, perhaps at the expense of the elected prefectoral tier. This has the advantage of satisfying the demands of decentralization that structural programmes require while permitting the centre to maintain strong influence over these programmes. Political devolution is, however, another matter. This form of devolution would make the Perifereia a Regional Government and would involve a greater loss of power and influence on the part of Central Ministries. Although political devolution is important, its 
absence does not indicate failure in the Greek reforms. To begin, it is important to consider that Greece has a long history with a centralized system. Hence, central actors may require more time to accept political decentralization. Further, administrative devolution itself may be an important step towards political devolution.

Law 1235 of 1982, had stated that the Prefectoral Councils were transitional institutions to prepare the way for new tiers of local government; this however, did not necessarily refer to the Prefectures. Indeed, on the basis of what senior officials in Athens stated, the emphasis may not be on the Prefectures. The central state has accepted the need for decentralization, but the programme is somewhat ambiguous. I was told by many Officials that we know from where we came, but we do not know where we are going. So they are cautiously progressing through the reform process. After some probing, however, I was able to ascertain that a three-tiered system of subnational governments will probably be off the agenda. The first level was needed, the question then becomes, 'Do we need both the third and the second?' (Interview with Senior Officials in the Ministry of the Interior). I was told that if the third tier becomes the elected tier, then the centre will exist alongside. The centre will not remain in its Ministries, the state will be represented and will execute responsibilities of an administrative character at the level resembling the present day Prefecture. So, there will be deconcentration and decentralization similar to that of France. Such a scenario however, would be in the distant future, perhaps in ten years (Interview with Central Officials). One reason for this delay is that time is needed so that the public becomes accustomed to the idea of the Perifereia. A second reason is that the centre wants to test 
how administrative decentralization is functioning (Interviews with Officials in the Ministry of the Interior). Finally, Prefectoral actors are quite mobilized, so it will be difficult for the centre to abolish the Prefectoral tier. Indeed, a number of central officials that I interviewed alluded to this difficulty. Prefects themselves stressed that the second level powers should be secured before reforms move to the $3^{\text {rd }}$ level. They argued that respect for the principle of subsidiarity would give powers to the Prefectures first and to the Perifereies second. At present, however, there are few demands stemming from the Perifereies. Although I cannot argue conclusively, if the Regional Secretary of West Greece is any indication of how other Regional Secretaries felt, then it appears that this level has not as yet acquired political aspirations. At the same time, there is tension between the regional tier and the central administration. So, in time, subnational mobilization may emerge at the regional tier.

The focus on the Perifereia is not really surprising. One could argue that the Perifereia corresponds to the geographic breakdown for the structural funds and hence, there is logic in directing reforms at this level. However, this does not explain why the Prefecture was initially the focus of PASOK's reforms yet has slowly receded to the background of its agenda. A more plausible explanation may be that the central government is trying to diffuse the threat of newly elected Prefectoral Councils by filling Regional posts with a viable administration capable of implementing $E U$ policy while under the 'control' of the centre. One can even argue that PASOK may have a long-term interest in establishing a proper regional government at the Perifereia and wants to ensure that powers will not be taken by the Prefectures during the transition. Drawing on the French experience, there is evidence that the postponement of regional elections 
enabled politicians from the départments and communes to seize many of the powers which the Regions may have occupied (Keating, 1983; Jouve, 1997). When elections at the regional level took place, there were not many powers left to be captured. So, in Greece, the transfer of powers to the regions in an administrative guise may actually work in the regions' favour.

Although everything is still in a state of dis-equilibrium, and it is still too soon to give a definitive verdict on the future model of Greek regionalization, the reforms are significant and they are not 'empty shells.' Much has happened in a relatively short period of time, and ta politica have been disturbed. Indeed, finding an interaction with the characteristics of a Mediterranean Regime in a country with such a long history of centralization is significant. While the Greek administration may not know exactly where they are going they have gone far.

\section{ACKNOWLEDGEMENTS}

This paper is taken from my unpublished Ph.D. Thesis completed in December 2001. Once again, I am enormously indebted to my advisor and friend, Michael Keating. I would also like to thank Officials in the Regional Policy Directorate of the European Commission, and Anastassios Bougas in particular, for assisting me in collecting data and for offering me space to work when I was in Brussels in April 2000. Further, I must warmly thank Jürg Steiner and my sister, Bess Vamvakas. Finally, the European University Institute in Florence also assisted the pursuit of my research by offering me the use of their research staff and library facilities during my stay in March-April 2000. 


\section{REFERENCES}

Amin, Ash (1999), "An Institutionalist Perspective on Regional Economic Development." International Journal of Urban and Regional Research. Vol. 23. No. 2. Pp. 365-78.

Balme, Richard and Jouve Bernard (1996), "Building the Regional State: Europe and Territorial Organization in France." in L. Hooghe ed. Cohesion Policy and European Integration. Oxford: Clarendon Press. Pp. 219-55.

Banfield, Edward (1958), The Moral Basis of a Backward Society. New York: The Free Press.

Bullmann, Udo (1997), "The Politics of the Third Level." in Charlie Jeffery ed. The Regional Dimension of the European Union. London: Frank Cass. Pp. 3-19.

Christofilopoulou, P. (1987), "Decentralization Policy in Post-Dictatorial Greece." Local Government Studies, Vol. 13, No. 6, November/December.

Christofilopoulou, P (1996), "Prefectural administration and self- government in the Greek Political System" in Hellenic Review of Political Science 7: Pp. 124-153.

DeRynck, Stefaan (1996), "Europe and Regional Policy-Making in the Flemish Regions." in op. cit. Cohesion Policy and European Integration. Pp. 129-62.

Fatouros, Arghyrios (1993), "Political and Institutional Facets of Greece's Integration in the European Community." in Psomiades and Thomadikis eds. Greece and the New Europe. New York: Pella. Pp. 23-42

Featherstone, Kevin (1994). "Political Parties," in P. Kazakos and P. Ioakimidis eds. Greece and EC Membership Evaluated. London: Pinter Publishers. Pp. 154-165.

Featherstone, Kevin and George Yannopoulos (1995), "The European Community and Greece: Integration and the Challenge to Centralism." in Michael Keating and Barry Jones eds. The European Union and the Regions. Oxford: Oxford University Press. Pp. 249-66.

Gellner, Ernest (1977), "Patrons and clients." in Ernest Gellner and John Waterbury eds. Patrons and Clients in Mediterranean Societies. London: Gerald Duckworth and Co. Ltd. Pp. 1-6.

Grémion, Jean-Pierre (1976), Le pouvoir Périphérique. Paris: Seuil.

Hooghe, Liesbet (1994), Building a Europe with the Regions. Discussion Paper No. 31 Oxford: Nuffield College.

Hooghe, Liesbet (1995), Subnational Mobilization in the European Union. EUI Working Papers. Florence: European University Institute.

Hooghe, Liesbet and Gary Marks (1995), "Channels of Subnational Representation in the European Union." in op. cit. What Model for the Committee of the Regions? Pp. 6-33.

Hooghe, Liesbet (1996), "Building a Europe with the Regions: The Changing Role of the European 
Commission." in op. cit. Cohesion Policy and European Integration. Pp. 89-126.

Hooghe, Liesbet (1996a), "Introduction." in op. cit. Cohesion Policy and European Integration. Pp. 124.

Hueglin, Thomas (1994), "Federalism, Subsidiarity and the European Tradition.” Telos. Vol. 27. Pp. 3755.

Ioakimidis, P.K. (1993), "Greece in the EC: Policies, experiences, and prospects". in op. cit. Greece and the New Europe. Pp. 405-20.

Ioakimidis, P.K. (1994), "The EC and the Greek political system: an overview." in op. cit. Greece and EC Membership Evaluated. London: Pinter Publishers. Pp. 139-165.

Ioakimidis, P. K. (1996), "EU Cohesion Policy in Greece: the tension between Bureaucratic centralism and regionalism." in op. cit. Cohesion Policy, the European Union and Subnational Mobilisation. Pp. 342-363.

Ioakimidis, P.K. (1996a), "Contradictions between policy and performance." in Kevin Featherstone and K. Ifantis eds. Greece in a Changing Europe. Manchester: Manchester University Press.

Ioakimidis, P.K. (1998) Europaiki Enosi kai Elliniko Kratos. Athens: Themelio.

Jeffery, Charlie (1997), “Conclusion: Sub-National Authorities and 'European Domestic Policy.' in op. cit. The Regional Dimension of European Integration. Pp. 204-219.

Jouve, Bernard (1997), "France: From the Regionalized State to the Emergence of Regional Governance?" in op. cit. The Political Economy of Regionalism. Pp. 347-69.

Kazakos, Panos (1991), Hellada Anamesa Prosargmogi kai Perithoriopoiise: Dokimia Europaikis kai Ikonomikis Politicis. Athens: Diatton.

Kazakos, Panos (1994), "Greece and the EC: historical review." in op. cit. Greece and EC Membership Evaluated. Pp. 1-9.

Kazakos, Panos (1994), "Summary and Prospects." in op. cit. Greece and EC Membership Evaluated. Pp. $1-9$.

Keating, Michael and Barry Jones eds. (1985), Regions in the European Community. Oxford: Oxford University Press.

Keating, Michael and Barry Jones eds (1995), Regions and the EuropeanUnion. Oxford: Oxford University Press.

Keating, Michael (1996), “Asymmetrical territorial devolution. Principles and practice.” Project on Federalism and Compounded Representation in Western Europe. June 1996.

Keating, Michael and Liesbet Hooghe (1996), "By-passing the Nation State? Regions and the EU Policy Process." in J.J. Richardson ed. Policy Making in the European Union. London: Routledge. Pp. 216-229.

Keating, Michael (1997). “The Political Economy of Regionalism.” In M. Keating and J. Loughlin eds. The Political Economy of Regionalism. London: Frank Cass. Pp. 17-40. 
Keating, Michael (1998) "Rethinking the Region. Culture, Institutions and Economic Development in Catalonia and Galicia.” Paper presented at the University of Utah Conference on Globalization, Regionalism and Governance. (September 1998).

Kernaghan, Kenneth (1995), "Keeping the new public management pot boiling." Canadian Public Administration. Vol, 38. No. 3 Autumn Pp. 481-485.

Ladréch, Robert (1994), “Europeanization of Domestic Politics and Institutions: The Case of France.” Journal of Common Market Studies. Vol. 32. No. 1 March 1994. Pp. 69-88.

Lavdas, Kostas A. ed. (1997), The Europeanization of Greece. Basingstoke: Macmillan.

Legg, Keith R. (1969), Politics in Modern Greece. Stanford: Stanford University Press.

Loughlin, John (1997), "Representing Regions in Europe: The Committee of Regions." in op. cit. The Regional Dimension of the European Union. Pp. 147-65.

Makridimitris, Ant. "Perifereiakos Diefthindis" Ta Nea. 17 April 1996.

Marks, Gary (1992), "Structural Policy in the European Community." in Alberta Sbragia ed. EuroPolitics. Washington: The Brookings Institute. Pp. 191-224.

Marks, Gary (1996), "Exploring and Explaining Variation in EU Cohesion Policy." in op. cit. Cohesion Policy and European Integration Pp. 338-422.

Médard, Jean-Françoise (1981), "Political Clientelism in France: The Centre-Periphery Nexus Reexamined." in op. cit. Political Clientelism, Patronage and Development. Pp. 124-171.

Mouzelis, Nicos (1990), "H Hellada sto Perithorio: Poios Ftaie?” To Byma. 30 December 1990.

Nanetti, Raffaella (1996), "EU Cohesion and Territorial Restructuring in the Member States" in op. cit. "The Making of European Cohesion Policy". Pp. 59-88.

Osborne, David and Ted Gaebler (1993), Reinventing Government. London: Penguin Publishers.

Papadopoulos, Kostas (1997), Eisigis tou Nomarchi Thessalonikis kai A’ Antiproedrou tis ENAE. Under the Ministry of the Interior on the subject: Prefectoral Self-rule, road and developmental prospects tou thesmou within the structure of Administrative Metarithmisis. May 1997.

Papadopoulos, Kostas (1997b), Prefect of Thessaloniki and Representatives of ENAE. Introduction for the $2^{\text {nd }}$ Convention of ENAE with the subject: "Prefectoral Self-rule the road and developmental prospects of the legislation within the structure of Administrative Reform" 1997.

Papageorgiou, Fouli and Susannah Verney (1992), "Regional Planning and the Integrated Role of Mediterranean Programmes in Greece." Regional Politics and Policy. Vol. 2. No. 1 Pp. 139161.

Piattoni, Simona (1997), "Local Political Classes and Economic Development." in op. cit. The Political Economy of Regionalism. Pp. 306-346.

Plaskovitis, Ilias (1994), "EC regional policy in Greece: ten years of structural funds intervention." in op. cit. Greece and EC Membership Evaluated. pp. 116-27.

Plaskovitis, Ilias (2000), "To trito koinotiko plaisio stirixis" in Kafkalos and Andropoulos (eds). $H$ 
Ellada: O Neos Europaikos Horos. Athens: Ta Themelia. Pp. 318-98.

Putnam, Robert (1993), Making Democracy Work: Civic Traditions in Modern Italy. Princeton: Princeton University Press.

Rhodes, R.A.W. (1985), "Power-Dependence, Policy Communities and Inter-Governmental Networks." Public Administration 49. Pp. 4-31.

Savoie, Donald J. (1995), "What is Wrong with the New Public Management." Canadian Public Administration. Vol. 38 No.1 Spring Pp. 112-138.

Schaefer, Guenther (1991), “The Rise and Fall of Subsidiarity.” Futures. Pp. 681-94.

Sharpe, L.J. ed. (1980), Decentralizing Trends in Western Democracies. London: Croom Helm.

Sharpe, L.J. (1993), The Rise of Meso Government in Europe. London: Sage.

Sotiropoulos, Dimitri (1993), "A Colossus with Feet of Clay: The State in Post-Authoritarian Greece." in op. cit. Greece, the New Europe, and the Changing International Order. Pp. 43-56.

Spanou, Calliope (1995), Penelope's Suitors: Administrative Modernization and Party Competition in Greece. Discussion Paper No. 38. Centre for European Studies. Nuffield College.

Spanou, Calliope (1998), "European Integration in administrative terms: a framework for analysis and the Greek case." Journal of European Public Policy. 5:3 September. Pp. 467-84.

Stoker, Gerry (1988), The Politics of Local Government. Basingstoke: MacMillan Education.

Stone, Clarence (1988), "Preemptive Power: Floyd Hunter's Community Power Structure Reconsidered" American Journal of Political Science. Vol. 32. No. 1 Pp. 82-104.

Stone, Clarence (1989), "Paradigms, Power, and Urban Leadership" in Bryan Jones ed. Leadership And Politics. United Press of Kansas. Pp. 135-59.

Stone, Clarence (1989b), Regime Politics: Governing Atalanta. 1946-1988. University Press of Kansas.

Stone, Clarence (1995), "Political Leadership in Urban Politics" in David Judge et. al. eds. Theories of Urban Politics. Pp. 96-116. London: Sage.

Storper, Michael (1997), The Regional World: Territorial Development In a Global Economy. New York: Guildford Press.

Tarrow, Sydney (1977), Between Centre and Periphery. New Haven: Yale University Press.

Thoening, Jean-Claude (1973), L’Ére des technocrats. Paris: Éditions d'Organisation.

Tsoukalas, Konstantinos (1993), “Free-riders in Wonderland.” Hellenic Political Science Review No. 1 (January, 1993). Pp. 9-32.

Vamvakas, Nancy (2001), Greece, the EU Structural Funds, and the Emergence of Mediterranean Regimes. Unpublished Ph.D. Thesis.

Verney, Susannah and Fouli Papageorgiou (1992), "Prefecture Councils in Greece: Decentralization in the 
European Community Context. Regional Politics and Policy Vol. 2 No. 1\&2. Spring/Summer 1992. Pp. 109-138.

Verney, Susannah (1994), "Central state-local government relations." in op. cit. Greece and EC Membership Evaluated. Pp. 166-79.

Verney, S. (1997), “Central state-local government relations" in op. cit. Lavdas, ed. The Europeanization of Greece.

Worms, Pierre (1966), “Le Préfet et ses notables.” Sociologie du travail. 3. Pp. 249-275.

The Citizen's State: To Kratos ton Politon Ministry of the Interior, Local Governance and Decentralization. Athens: October, 1997.

Memo from the Ministry of the Interior, Public Administration and Decentralization: Dated 4 February 1999. 